\title{
PHARMACOGENETICS IN CLINICAL PRACTICE: CHALLENGES AND OPPORTUNITIES
}

\section{FARMAKOGENETIKA U KLINIČKOJ PRAKSI: IZAZOVI I MOGUĆNOSTI}

\section{Summary}

Pharmacogenetics studies the influence of genetic variation on drug response, while pharmacogenomics is a genome - wide and multifactorial extension of the term pharmacogenetics. Both pharmacogenetics and pharmacogenomics are the backbones of the concept called personalized medicine. Although a "personalized" approach has always been a goal of good medical practice, there is a new aspect of the extensive use of molecular data to tailor drug therapy to an individual patient, in order to maximize therapeutic benefit and minimize adverse events.

The main causes of inter - individual variability in a patient are genetic variations in genes responsible for enzymes synthesis, which participate in absorption, distribution, metabolism and excretion (ADME system) of drugs. So, all patients can be classified in four groups, according to their genotype: slow metabolizers, intermediate metabolizers, ultrafast metabolizers and extensive metabolizers who are most frequent and are considered to be a standard group of patients. The group of most essential metabolism enzymes is represented by a superfamily of cytochrome P450 (CYP2D6, CYP2C9, CYP2C19, etc.). Enzymes from this family contribute to inter - individual differences in drug concentration in the plasma. The effects of polymorphisms in the CYP P450, range from an ineffective drug therapy to severe toxicity it can cause (e.g. drugs with a narrow therapeutic range (e.g., Warfarin) in patients with a reduced activity of CYP P450).

Pharmacogenetic testing is carried out for a number of reasons: for selecting patients most likely to achieve therapeutic efficacy, in order to reduce side effects and determine the most appropriate dose, in order to achieve efficiency and a higher degree of therapy safety. The advantage of pharmacogenetic testing is reflected in the fact that it can be applied prior to drug application. Pharmacogenetics should satisfy patients' need for an effective therapy without side effects, physicians' need for assistance in selecting an adequate remedy and dosage for a particular patient, as well as other health care professionals, government agencies and pharmacists' needs.

Key words: pharmacogenetics, genetic polymorphisms, CYP 450, personalized medicine.

\section{Sažetak}

Farmakogenetika proučava uticaj genetskih polimorfizama na terapijski odgovor određenog leka, dok farmakogenomika pored uticaja gena ispituje i ostale multifaktorijalne uticaje interindividualnih, tj. intraindividualnih odgovora na propisanu standardnu terapiju. Individualni pristup, odnosno personalizovana terapija predstavlja osnovni cilj farmakogenetike, u kome je od ključne važnosti postići maksimalni terapijski uspeh, uz istovremeno postizanje minimalnog broja pratećih neželjenih efekata propisane terapije.

Osnovni uzrok interindividualne varijabilnosti pacijenata su genetičke varijacije (pojedinačni nukleotidni polimorfizmi) u genima zaduženim za sintezu enzima koji učestvuju u procesu apsorpcije, distribucije, metabolizma $i$ eliminacije lekova. Svi pacijenti se mogu podeliti na osnovu svog genotipa na 4 klase: spori metabolizeri, intermedijarni metabolizeri, ultrabrzi metabolizeri i ekstenzivni metabolizeri koji su i najčešće zastupljeni i smatraju se standardnom grupom pacijenata. Najbitniju grupu ovih enzima predstavlja superfamilija citohroma P450 (CYP2D6, CYP2C9, CYP2C19, itd). Enzimi iz ove familije doprinose interindividualnim razlikama u koncentraciji lekova u plazmi. Tako se posledice polimorfizama CYP P450 kreću se od neefikasne medikamentozne terapije do ozbiljnih toksičnosti koje ona može prouzrokovati. Jedan takav primer predstavljaju lekovi uske terapijske širine (npr. varfarin, opšti anestetici, citostatitici, itd.) kod pacijenata sa smanjenom aktivnošću CYP P450.

Kada je reč o kliničkoj primeni, od farmakogenetike svi mnogo očekuju: pacijenti koji zahtevaju efikasnu terapiju bez neželjenih efekata, lekari kojima je potrebna pomoć u izboru adekvatnog leka i doze za određenog pacijenta, zdravstveni radnici koji moraju da pronađu način da unaprede kvalitet zdravstvene zaštite uz istovremeno smanjenje troškova, vladine agencije kojima su potrebna pouzdana ispitivanja prilikom izdavanja terapijskih vodiča i zakona, kao i farmaceutskoj industriji koja nastoji da skupe supstance, koje pretenduju da postanu lek, ne izgube usled nepredvidene toksičnosti u kasnim fazama razvoja leka.

Ključne reči: farmakogenetika, genetski polimorfizmi, CYP P450, individualna terapija. 
UvoD

Farmakogenetika je disciplina koja istražuje uticaj genetskih polimorfizama na terapijski odgovor, odnosno na efikasnost i bezbednost leka. Cilj farmakogenetike je personalizovana terapija, u okviru koje bi se mogao prepisati najefikasniji lek $\mathrm{u}$ adekvatnoj dozi za pojedinačnog pacijenta. Iako je „personalizovani“ pristup lečenju oduvek bio znak dobre medicinske prakse, detaljno korišćenje molekularnih podataka prilikom „krojenja“ terapije po meri određenog pacijenta, u cilju poboljšanja terapeutskog ishoda i smanjenja neželjenih dejstava, pruža sasvim novi aspekt lečenja.

Farmakogenetika se napaja sa dva glavna istraživačka izvora, osnovnog koji nastoji da otkrije genetske polimorfizme i razume biološke genotipsko-fenotipske odnose, i klinički orijentisanog izvora koji se nadovezuje na osnovno znanje $\mathrm{u}$ istraživanju odnosa genetskih faktora i fenotipova terapijskog odgovora, i primene novih dijagnostičkih procedura u njegovom prenošenju u kliničku praksu.

\section{FARMAKOGENETIKA U KLINIČKOJ PRAKSI}

Svakodnevna praksa pokazuje da nemaju svi pacijenti isti farmakološki odgovor na primenjenu standardnu terapiju. Neki pacijenti imaju zanemarljivu korist od terapije, dok kod drugih ista terapijska doza dovodi do pojave neželjenih i toksičnih efekata $[1,2]$.

Farmakogenetika/farmakogenomika proučava ulogu genetskih faktora u dispoziciji i odgovoru na lek. Pored toga, faktori okruženja (navike u ishrani, pušenje, istovremena primena drugih lekova, izloženost toksičnim materijama), fiziološke razlike (uzrast, pol, pridružene bolesti, trudnoća) i komplijansa pacijenata, zajedno doprinose interindividualnim varijacijama u metabolizmu leka i posledičnom terapijskom odgovoru.

Terapeutski monitoring leka (Therapeutic Drug Monitoring; TDM), kao najranija personalizovana terapijska procedura kod primene određenog leka, se sprovodi tek nakon davanja leka, dok se farmakogenetička testiranja mogu sprovesti i pre nego što se započne s terapijom. Farmakogenetičko testiranje je univerzalno za mnoge lekove i dovoljno je sprovesti ga samo jednom. Na osnovu činjenice da nije uvek moguće razdvojiti faktore životne sredine od genetskih uticaja kao uzroke varijabilnosti u odgovoru na lek, kombinovanje klasičnog TDM (fenotipska strategija) i genotipizacije metaboličkih svojstava leka, trenutno se smatra najsofisticiranijim načinom individualizacije doziranja pojedinih lekova [3-6].

\section{FARMAKOGENETIČKA ISTRAŽIVANJA}

Jedan od mogućih uzročnika interindividualne varijabilnosti su genetičke varijacije. Od posebnog značaja su pojedinačni nukleotidni polimorfizmi (PNP) gena koji kodiraju sintezu enzima zaduženih za metabolizam i transport lekova [7].

Najveći stepen PNP-a nađen je u genima uključenim u metabolizam lekova; odnosno metabolizam približno 40\% lekova koji se nalaze u svakodnevnoj kliničkoj praksi se odvija pod dejstvom enzima čiju sintezu kodiraju geni sa PNP-om [8]. Trenutno su najbitniji ovakvi enzimi superfamilije citohrom P450 (kao što su CYP2D6, CYP2C9, CYP2C19, CYP2C8, CYP3A4, CYP3A5), tiopurin metil transferaza (TPMT), uridin difosfat glukuronosil transferaza (naročito UGT1A1, UGT1A4, UGT2B7), N-acetil transferaza 2 (NAT2), dihidro pirimidin dehidrogenaza (DPD) i organski katjonski transporter 1 (OCT1) [5, 9-12].

Međutim, danas se zna da i geni koji nemaju veze sa farmakokinetičkim svojstvima lekova, utiču na terapijski učinak ili bezbednost lekova. Takvi geni mogu direktno da utiču na receptore, odnosno sisteme transdukcije lekova, ili mogu biti samo indirektno povezani sa farmakodinamičkim mehanizmima dejstva leka. Na primer, gen ADRB2 koji kodira beta-2 adrenergički receptor i njegova dva nesinonimna pojedinačna nukleotidna polimorfizma (Arg16Gly i Glu27Gln) intenzivno se proučavaju da bi se jasno odredila njihova uloga u terapiji teških oblika astme $[13,14]$.

\section{CITOHROM P450}

\section{Subpopulacione podele pacijenata na osnovu genotipa/lokusa}

$\mathrm{Na}$ osnovu svog genotipa/lokusa, svi pacijenti mogu se podeliti u četiri klase: spori metabolizeri (SM), intermedijarni metabolizeri (IM), ekstenzivni metabolizeri (EM) i ultrabrzi metabolizeri (UM). Ekstenzivni metabolizeri su najčešće zastupljeni i smatraju se standardnom grupom pacijenata. Opis ove klasifikacije zajedno sa posledicama dejstva prilikom postojanja razlike u parovima gena na efikasnost, odnosno toksičnost lekova prikazan je u tabeli 1. [3].

\section{Klinički značaj polimorfizma CYP P450}

Opšte je prihvaćeno da varijacije u genima koji kodiraju enzime iz familije citohrom P450 (P450) doprinose interindividualnim razlikama u koncetraciji lekova u plazmi, što dovodi do varijabilnosti u efikasnosti i bezbednosti primenjenog leka kod različitih pacijenata.

Moguće posledice polimorfizma CYP P450 kreću se u rasponu od ozbiljne toksičnosti do neefikasne medikamentozne terapije. Genetski određeno smanjenje enzimske aktivnosti CYP P450 može imati važne implikacije kod lekova uske terapijske širine kao što su varfarin, kod koga povećane koncetracije u plazmi dovode do toksičnosti. U slučaju prolekova, kao što su kodein ili klopidogrel, slaba 
Tabela 1. Farmakogenetička klasifikacija pacijenata na osnovu genotipa/lokusa [3]

\begin{tabular}{l|l} 
& Par gena \\
Klasa & Raspored alela \\
$\begin{array}{l}\text { Spori metabolizeri } \\
\text { (SM) }\end{array}$ & $\begin{array}{l}\text { Obe pozicije u genu koje čine } \\
\text { par imaju varijantu koja rezul- } \\
\text { tira nefunkcionalnim ili odsut- } \\
\text { nim proteinom. }\end{array}$
\end{tabular}

Intermedijarni Jedan član u genskom paru pometabolizeri (IM) seduje varijantu koja rezultira nefunkcionalnim ili odsutnim proteinom, a drugi poseduje varijantu koja rezultira proteinom smanjene funkcionalnosti.

\section{Očekivani uticaj na aktivni lek}

Smanjena efikasnost $\mathrm{u}$ konverziji aktivnog leka u neaktivni metabolit. Povećan rizik od viših koncentracijskih nivoa aktivnog leka i posledične kliničke toksičnosti.

Smanjena efikasnost u konverziji aktivnog leka u neaktivni, povećava rizik od povišenih nivoa aktivnog leka i kliničke toksičnosti. Započinjanjem primene leka u malim dozama, postepenim povećanjem, efikasnost se postiže ranije nego kod EM.

Ekstenzivni me- Svaki član para ima sekvencu tabolizeri (EM) konzistentnu s potpuno funkcionalnim proteinom.

Ultrabrzi metabolizeri (UM)
Aktivni lek primenjen u standardnoj dozi metabolisan u neaktivne komponente, postiže efikasnost bez ili uz minimalne neželjene efekte.

Povećana efikasnost konverzije aktivnog leka u neaktivni metabolit i povišen rizik of smanjene efikasnosti pri standardnim dozama.

\section{Očekivani uticaj na prolek}

Nesposobnost da se prolek konvertuje $\mathrm{u}$ aktivni metabolit. Ukoliko prolek nema terapijska svojstva, efikasnost neće biti zadovoljavajuća uprkos povećanim dozama.

Smanjena efikasnost konverzije neaktivnog proleka u aktivni metabolit. Očekivano smanjenje efikasnosti prilikom standardnih doza održavanja.

Prolek konvertovan u aktivni metabolit postiže efikasnost bez ili uz minimalne neželjene efekte.

Povećana efikasnost konvertovanja proleka u aktivne metabolite, i s tim povezan povišen rizik od toksičnosti usled viših nivoa aktivnih metabolita od očekivanih. enzimska aktivnost može da spreči postizanje terapeutskih koncentracija u plazmi i da dovede do terapijskog neuspeha. Međutim, dupliranje gena CYP2D6 može izazvati toksične reakcije na kodein, usled akumulacije aktivnih metabolita. Za lekove široke terapijske širine, kao što su selektivni inhibitori preuzimanja serotonina i beta-blokatori, kliničke implikacije varijacija gena CYP P450 imaju nešto manji klinički značaj. Tako na primer, nasledni nedostatak CYP2C9 može ostati nedetektovan u toku života pojedinca, osim ukoliko mu nije propisan lek uske terapijske širine, kao što je varfarin, koga metaboliše CYP2C9. Slično tome, pojedinac sa neaktivnim CYP2D6 može proći bez ijednog neželjenog efekta, osim ako ne uzima lek kao što je tioridazin, koji može proizvesti štetne posledice na srčani rad kod sporih metabolizera CYP2D6.

Genotipski testovi kojima se detektuju varijacije mnogih P450 gena danas su dostupni u komercijalne svrhe. Imajući u vidu raspon lekova čijeg metabolizma nema bez aktivnog učešća CYP P450, upotreba takvih testova mogla bi omogućiti pristup širokoj implementaciji individualizacije medikamentozne terapije. Do sada je funkcionalni polimorfizam otkriven za gene CYP2A6, CYP1A2, CYP2C9, CYP2C19, CYP2D6 i CYP3A4/5. Danas najmanje 25 lekova u svojim uputstvima, koje je odobrila Uprava za hranu i lekove (US Food and Drug Administration; FDA) sadrži 
Tabela 2. Primeri lekova čije uputstvo sadrži informacije o genotipu [15-30]

Lek Genotip Klinička implikacija

\section{Antidepresivi, anksiolitici i antipsihotici}

\begin{tabular}{|c|c|c|}
\hline Aripiprazol & CYP2D6 & Povećana izloženost leku kod SM CYP2D6; preporučuje se smanjenje doze. \\
\hline Klozapin & CYP2D6 & $\begin{array}{l}\text { Moguće povećanje koncentracije u plazmi kod SM CYP2D6; nejasan klinički } \\
\text { značaj. }\end{array}$ \\
\hline Diazepam & CYP2C19 & Povećana enzimska aktivnost može dovesti do pojačane sedacije. \\
\hline Doksepin & CYP2D6 & Povećana koncentracija u plazmi kod SM CYP2D6; potrebno smanjiti dozu. \\
\hline Fluoksetin & CYP2D6 & Povećana koncentracija u plazmi S-fluoksetina kod SM; nejasan klinički značaj. \\
\hline Protriptilin & CYP2D6 & Povećana koncentracija u plazmi kod SM CYP2D6; potrebno smanjiti dozu. \\
\hline Risperidon & CYP2D6 & Povećana koncentracija u plazmi kod SM CYP2D6; klinički značaj nejasan. \\
\hline Tioridazin & CYP2D6 & $\begin{array}{l}\text { Povećana koncentracija u plazmi kod SM CYP2D6; što povećava rizik od lekom } \\
\text { izazvane prolongacije QT-intervala i aritmija [16]. Tioridazin je kontraindiko- } \\
\text { van kod SM CYP2D6. }\end{array}$ \\
\hline Venlafaksin & CYP2D6 & $\begin{array}{l}\text { Povećana koncetracija u plazmi kod SM CYP2D6; može povećati rizik od neže- } \\
\text { ljenih efekata. }\end{array}$ \\
\hline
\end{tabular}

\section{Analgetici}

$\begin{array}{lll}\text { Celekoksib } & \text { CYP2C9 } & \begin{array}{l}\text { Povećana izloženost leku kod onih sa alelima smanjene funkcionalnosti CY- } \\ \text { P2C9;. Kod pacijenata sa }{ }^{*} /{ }^{*} 3 \text { genotipom neophodno smanjiti dozu. }\end{array} \\ \text { Kodein } & \text { CYP2D6 } & \text { Smanjen nivo morfina u plazmi i analgetski efekat kod SM CYP2D6 [17-20]. } \\ \text { Tramadol } & \text { CYP2D6 } & \begin{array}{l}\text { Smanjen nivo O-dezmetiltramadola u plazmi ismanjen analgetski efekt kod SM } \\ \text { CYP2D6 [17-20]. }\end{array}\end{array}$

\section{Kardiovaskularni lekovi}

\begin{tabular}{|c|c|c|}
\hline Karvedilol & CYP2D6 & $\begin{array}{l}\text { Povećan nivo } R \text {-karvedilola u plazmi kod SM CYP2D6; potencijalno povećan } \\
\text { rizik od neželjenih efekata, kao što je vrtoglavica. }\end{array}$ \\
\hline Klopidogrel & CYP2C19 & $\begin{array}{l}\text { Samnjen antiagregacioni efekat kod SM CYP2C19; moguć povećan rizik od } \\
\text { neželjenih kardiovaskularnih poremećaja, uključujući i trombozu stenta [21, } \\
22] \text {. }\end{array}$ \\
\hline Metoprolol & CYP2D6 & Povećan nivo u plazmi kod SM CYP2D6; nejasan klinički značaj $[23,24]$. \\
\hline Propafenon & CYP2D6 & Povećan nivo u plazmi kod SM CYP2D6; nejasan klinički značaj. \\
\hline Propranolol & CYP2D6 & Povećan nivo u plazmi kod SM CYP2D6; nejasan klinički značaj $[23,24]$. \\
\hline Varfarin & CYP2C9 & $\begin{array}{l}\text { Smanjen klirens S-varfarina kod nosilaca alela CYP2C9 smanjene metaboličke } \\
\text { funkcije; potrebno smanjiti dozu; povećan rizik od krvarenja [25-28]. }\end{array}$ \\
\hline \multicolumn{3}{|c|}{ Inhibitori protonske pumpe } \\
\hline Omeprazol & CYP2C19 & Potencijalno smanjena efikasnost kod EM CYP2C19 u poređenju sa SM [29]. \\
\hline Rabeprazol & CYP2C19 & Potencijalno smanjena efikasnost kod EM CYP2C19 u poređenju sa SM [30]. \\
\hline
\end{tabular}

Skraćenice: SM - spori metabolizeri; EM - ekstenzivni metabolizeri; IM - intermedijarni metabolizeri

farmakogenetičke informacije koje se odnose na P450 enzime [15]. Primeri ovakvih lekova dati su u tabeli 2. Na uputstvima se od P450 gena pominju CYP2C9, CYP2C19 i CYP2D6. Upravo zato je ovaj pregledni rad fokusiran na genetske varijacije bitne za enzime CYP2C9, CYP2C19 i CYP2D6 kao i lekove koje metabolišu navedeni enzimi.

\section{CYP2 29 GENOTIP}

Enzim CYP2C9 metaboliše približno 15\% lekova sa kliničkom primenom, uključujući i neke antikoagulante (npr. $S$-varfarin), hipoglikemike (npr. tolbutamid), blokatore receptora angiotenzina II (npr. losartan), antiepileptike (npr. fe- 
nitoin) i nesteroidne antiinflamatorike (npr. diklofenak) [31]. Do danas je identifikovano 35 varijanti gena CYP2C9 [32].

\section{Uticaj CY P2C9 genotipa na terapijsku efikasnost varfarina}

Varafin je najčešće propisivan lek za prevenciju tromboembolije. Ima usku terapijsku širinu i dozira se prema internacionalnom normalizovanom odnosu (International Normalised Ratio, INR), pa se za većinu indikacija preporučuje INR ospeg 2 ili 3 [33]. Rizik od tromboze raste kod primene antikoagulacijskih doza ispod terapijskog nivoa [34, 35], dok INR opseg veći od 4 povećava rizik od krvarenja. Varfarin je lek koji je izazovno kontrolisati, velikim delom zbog toga što doza neophodna da bi se postigao terapijski efekat varira i dvadesetostruko kod različitih pacijenata [36].

Kao pomoć lekarima u određivanju doze varfarina, kada je poznat genotip CYP2C9, publikovano je više algoritama [37-40]. Mnogi lekari i zdravstveni radnici očekuju rezultate kliničkih istraživanja, koja su u toku, pre nego što u potpunosti usvoje protokole za doziranje varfarina na osnovu genotipa.

\section{CYP2C19 GENOTIP}

\section{Funkcionalnost varijanti CYP2C19}

Enzim CYP2C19 metaboliše pribižno 10\% lekova u kliničkoj praksi, uključujući $S$-mefenitoin, inhibitore protonske pumpe i nelfinavir. Enzim CYP2C19 takođe je odgovoran za biotransformaciju klopidogrela u farmakološki aktivan oblik. Genetski nedostatak u CYP2C19 posredovanoj eliminaciji $S$-mefenitoina prvi put je zabeležen 1979.godine [41]. Do danas je identifikovano 28 varijanti CYP2C19 gena [42].

\section{Uticaj genotipa CYP2C19 na terapijsku efikasnost klopidogrela}

Klopidogrel je antiagregacioni lek koji se nalazi u širokoj upotrebi kod pacijenata sa kardiovaskularnim oboljenjima. Pokazalo se da klopidogrel, u kombinaciji sa aspirinom, smanjuje morbiditet i mortalitet pacijenata sa akutnim koronarnim sindromom (ACS), koji se leče medikamentoznom terapijom ili koronarnom revaskularizacijom [43-45]. Dualna antiagregaciona terapija koja se sastoji od klopidogrela i aspirina, takođe smanjuje rizik od koronarne tromboze stenta, nakon perkutane koronarne intervencije (PCI) [46]. Kod različitih pacijenata efikasnost klopidogrela znatno varira, pa se kod $25 \%$ pacijenata koji su primili terapiju javlja rezidualna ex vivo agregacija trombocita [47]. Kod ovakvih pacijenata postoji povećan rizik od ozbiljnih neželjenih srčanih stanja, kao što su infarkt miokarda i tromboza stenta.

Uputstvo za primenu klopidogrela ažurirano je u martu 2010.godine kao odgovor na izveštaje o smanjenoj efikasnosti u prisustvu alela CYP2C19 smanjene metaboličke funkcionalnosti [48]. Uputstvo upozorava na smanjenu efikasnost kod sporih metabolizera i navodi da je dostupno genetsko testiranje na alele CYP2C19 smanjene funkcionalnosti. Uputstvo dalje savetuje zdravstvene radnike da razmotre alternativne opcije za pacijente označene kao SM. Međutim, uputstvo ne precizira u kojim slučajevima bi trebalo raditi genotipizaciju, kao ni koje korake preduzeti kod pacijenata kojima se testom utvrdi prisustvo alela smanjene metabličke funkcionalnosti. Osim toga, uputstvo ne pominje IM, koji su jasno u povećanom riziku od kardiovaskularnih poremećaja u poređenju sa EM, mada manjem od SM.

Nedavno je konzorcijum za kliničku implementaciju farmakogenetike, podržan od strane američkog Nacionalnog instituta za zdravlje (Nacional Institutes of Health, NIH), publikovao vodiče za genotipom navođenu antiagregacionu terapiju kardiovaskularnih bolesti [49]. Ovi vodiči ne daju čvrste preporuke o tome koje pacijente treba genotipizovati, već nude dva potencijalna pristupa. Prema prvom, svi pacijenti koji imaju ACS, ili im je izvršena PCI, treba da budu genotipizirani, dok su prema drugom, $u$ fokusu pacijenti sa visokim i umerenim rizikom, kao što su oni sa istorijom tromboze stenta, dijabetesa, insuficijencije bubrega, ili onih sa visokorizičnim koronarnim angiografskim karakteristikama. Kod pacijenata za koje postoje podaci o CYP2C19 genotipu, standardne doze klopidogrela se preporučuju za EM i UM. Alternativna terapija prasugrelom, tikagrelorom ili cilostazolom preporučujuje se za IM ili SM [49].

\section{Uticaj genotipa CYP2C19 na terapijsku efikasnost}

inhibitora protonske pumpe

Inihibitori protonske pumpe (IPP), kao što su omeprazol, esomeprazol, pantoprazol, lansoprazol i rabeprazol su prolekovi i delimično se metabolišu zahvaljujući CYP2C19. Aleli CYP2C19 smanjene metaboličke funkcionalnosti povećavaju koncentraciju inhibitora protonske pumpe u plazmi i stvaraju veću supresiju želudačne kiseline [50-52]. U skladu s ovim podacima stoji činjenica da se viša stopa eradikacije Helicobacter pylori postiže ili uz pomoć dualne (IPP i amoksicilin) ili triple (IPP, amoksicilin i klaritromicin) terapije kod pacijenata sa defektnim alelom CYP2C19. To naročito važi u pogledu prijavljenih stopa izlečenja standardnim dozama omeprazola (20 $\mathrm{mg} / \mathrm{dan}$ ) i amoksicilina od $100 \%, 60 \%$ i $29 \%$ za EM [29]. Genotip CYP2C19 takođe utiče na efikasnost inhibitora protonske pumpe u lečenju gastroezofagealnog refluksa.

Slično CYP2C9, postoje podaci da se ekspresija gena CYP2C19 menja tokom odrastanja, pri čemu se puna ekspresija dostiže tek sa 10 godina starosti [53]. Kao posledica toga, odnos između genotipa CYP2C19 i odgovora na inhibitor protonske pumpe može da se razlikuje između odraslih i pedijatrijskih pacijenata [53]. 


\section{GENOTIP CYP2D6}

Enzim CYP2D6 metaboliše oko 25\% lekova sa kliničkom primenom iz više različitih klasa kao što su antidepresivi, antipsihotici, antihipertenzivi i analgetici.

\section{Uticaj genotipa CYP2D6 na terapijsku efikasnost opioidnih analgetika}

Kodein i tramadol su prolekovi koji se uz pomoć CYP2D6 konvertuju u svoje aktivne metabolite morfin, odnosno O-desmetiltramadol. Spori metabolizeri CYP2D6 postižu niže koncentracije metabolita, pa je analgetski efekat pri uobičajenim dozama ovih lekova minimalan [17-20]. Za razliku od toga, pacijenti sa dupliranim genom CYP2D6 i fenotipom ultrabrzog metabolizma nakon uzimanja kodeina ili tramadola, u riziku su od toksičnih koncentracija morfina i O-desmetiltramadola u plazmi [54-56]. Postoje izveštaji o ozbiljnim respiratornim depresijama i bolovima $\mathrm{u}$ abdomenu kod pacijenata koji su primali analgetike na bazi kodeina, a za koje je naknadno utvrđeno da imaju fenotip ultrabrzog metabolizma $[55,56]$. Pored toga, prijavljeni su i slučajevi teške opioidne toksičnosti, pa čak i smrtni slučajevi, kod odojčadi koje su dojile majke sa fenotipom ultrabrzog metabolizma (UM) [57]. Ovi podaci ukazuju na to da analgetike koji sadrže kodein i tramadol treba davati samo pacijentima koji pripadaju fenotipu EM, da bi se izbegli analgetski neuspeh kod SM, odnosno toksičnost kod UM.

\section{FARMAKOGENETSKO TESTIRANJE \\ U KLINIČKOJ PRAKSI}

Farmakogenetičko testiranje se vrši prevashodno zbog nekoliko razloga: u selekciji pacijenata sa najvećim izgledima za postizanje terapijske efikasnosti, u cilju smanjenja neželjenih efekata i određivanju adekvatne doze leka kako bi se postigle efikasnost i što veći stepen bezbednosti primenjene terapije. Noviji podaci ukazuju na to da je većina propisanih lekova efikasna kod ne više od $60 \%$ osoba koje ih uzimaju, a znatan broj pacijenata razvije neki od ozbiljnih neželjenih efekata, koji često zahtevaju hospitalizaciju. Klinička i regulatorna zajednica prepoznale su u širokom spektru farmakogenetičkih testova ozbiljan potencijal kako bi se izmenila postojeća standardna medicinska praksa. Tako su danas informacije o genetičkom testiranju sastavni deo uputstava za upotrebu nekih od lekova, kao što su abakavir, varfarin, klopidogrel, irinotekan, maravirok, cetuksimab itd. [5].

\section{IZAZOVI U KLINIČKIM ISTRAŽIVANJIMA}

Više od 200 registrovanih lekova u svetu, što čini oko $10 \%$ lekova odobrenih od strane FDA, sadrži farmakogenetičke informacije, što je još uvek mali broj lekova. Ipak, navedeni podatak pokazuje potencijalni značaj odnosa između genetskih polimorfizama i farmakokinetike odnosno terapijskog odgovora.
Kada je reč o kliničkoj primeni, od farmakogenetike svi mnogo očekuju: pacijenti koji zahtevaju efikasnu terapiju bez neželjenih efekata, lekari kojima je potrebna pomoć $\mathrm{u}$ izboru adekvatnog leka i doze za određenog pacijenta, zdravstveni radnici koji moraju da pronađu način da unaprede kvalitet zdravstvene zaštite uz istovremeno smanjenje troškova, vladine agencije kojima su potrebna pouzdana ispitivanja prilikom izdavanja terapijskih vodiča i zakona, kao i farmaceutskoj industriji koja nastoji da skupe supstance, koje pretenduju da postanu lek, ne izgube usled nepredviđene toksičnosti u kasnim fazama razvoja leka.

\section{LITERATURA}

1. Pickar D, Rubinow K. Pharm acogenomics of psychiatric disorders. Trends Pharmacol. Sci. 2001; 22 (2): 75-83.

2. Kliegman R, Nelson M.Textbook of Pediatrics. Elsevier, Amsterdam. 2007

3. Ginsburg S, Willard F. Genomic and personalized medicine: foundations and applications. Transl. Res.2009; 154 (6):277-287.

4. Amos C, Burke W, Caskey T. Applications of Toxicogenomic Technologies to Predictive Toxicology and Risk Assessment. National Academies Press, Washington D.C.2007.

5. Gervasini G, Benítez J, Carrillo A. Pharmacogenetic testing and therapeutic drug monitoring are complementary tools for optimal individualization of drug therapy. Eur. J. Pharmacol.2010; 66:755-774.

6. Crews R, Cross J, McCormick N, Baker K., Molinelli R, Mullins R, Relling V, Hoffman M. Development and implementation of a pharmacist-managed clinical pharmacogenetics service. Am. J. Health Syst. Pharm.2011; 68:143-150.

7. Riedlová R, Richterová R. Farmakogenetika v laboratorní praxi. FONS informační bulletin.2008;18: 20-23.

8. Phillips A, Veenstra L., Oren E, Lee K, Sadee W. Potential role of pharmacogenomics inreducing adverse drug reactions: a systematic review. JAMA 2001; 286:2270-2279.

9. Ingelman-Sundberg M. Pharmacogenetics of cytochrome P450 and its applications in drug therapy: the past, present and future. Trends Pharmacol. Sci.2004; 25(4):193-200.

10. Slanar O. Farmakogenetika v klinické praxi. Farmakoterapie 2005; 3:296-298.

11. Becker M, L, Visser E, van Schaik N, Hofman A, Uitterlinden G, Stricker $\mathrm{Ch}$. OCT1polymorphism is associated with response and survival time in anti-Parkinsonian drug users. Neurogenetics 2011;12:79-82.

12. Luxembourg B, Schneider K, Sittinger K., Toennes W, Seifried E, Lindhoff-Last E, Oldenburg J, Geisen C. Impact of pharmacokinetic (CYP2C9) and pharmacodynamic (VKORC1, F7, GGCX, CALU, EPHX1) gene variants on the initiation and maintenance phases of phenprocoumon therapy. Thromb. Haemost.2011;105(1):169-180.

13. Chung P, Waterer G, Thompson J. Pharmacogenetics of $\beta 2$ adrenergic receptor genepolymorphisms, long-acting $\beta$-agonists and asthma. Clin. Exp. Allergy 2011; 41(3):312-326.

14. Tse M, Tantisira K., Weiss T. The pharmacogenetics and pharmacogenomics of asthma therapy. Pharmacogenomics J. 2011; 11(6):383-392.

15. US Food and Drug Administration. Table of pharmacogenomic biomarkers in drug labels [web page on the Internet]. Silver Spring, MD: US Food and Drug Administration; 2011 [updated September 27]. Available from: http://www.fda.gov/Drugs/ScienceResearch/ ResearchAreas/ Pharmacogenetics/ucm083378.htm. Accessed September 29, 2011.

16. Llerena A, Berecz R, de la Rubia A, Dorado P. QTc interval lengthening is related to CYP2D6 hydroxylation capacity and plasma concentration of thioridazine in patients. J Psychopharmacol. 2002; 16(4):361-364.

17. Eckhardt K, Li S, Ammon S, et al. Same incidence of adverse drug events after codeine administration irrespective of the genetically determined differences in morphine formation. Pain. 1998; 76(1-2):27-33. 
18. Sindrup SH, Brøsen K, Bjerring P, et al. Codeine increases pain thresholds to copper vapor laser stimuli in extensive but not poor metabolizers of sparteine. Clin Pharmacol Ther. 1990; 48(6):686-693.

19. Stamer UM, Lehnen K, Höthker F, et al. Impact of CYP2D6 genotype on postoperative tramadol analgesia. Pain. 2003;105 (1-2):231-238.

20. Wang G, Zhang H, He F, Fang X. Effect of the CYP2D6*10 C188T polymorphism on postoperative tramadol analgesia in a Chinese population. Eur J Clin Pharmacol. 2006; 62(11):927-931.

21. Mega JL, Close SL, Wiviott SD, et al. Cytochrome $\mathrm{p}-450$ polymorphisms and response to clopidogrel. N Engl J Med. 2009; 360 (4): 354-362.

22. Mega JL, Simon T, Collet JP, et al. Reduced-function CYP2C19 genotype and risk of adverse clinical outcomes among patients treated with clopidogrel predominantly for PCI: a meta-analysis. JAMA. 2010; 304(26):1821-1830.

23. Rau T, Wuttke H, Michels LM, et al. Impact of the CYP2D6 genotype on the clinical effects of metoprolol: a prospective longitudinal study. Clin Pharmacol Ther. 2009; 85(3):269-272.

24. Terra SG, Pauly DF, Lee CR, et al. beta-Adrenergic receptor polymorphisms and responses during titration of metoprolol controlled release/ extended release in heart failure. Clin Pharmacol Ther. 2005; 77(3):127-137.

25. Scordo MG, Pengo V, Spina E, Dahl ML, Gusella M, Padrini R. Influence of CYP2C9 and CYP2C19 genetic polymorphisms on warfarin maintenance dose and metabolic clearance. Clin Pharmacol Ther. 2002; 72(6):702-710.

26. Takahashi H, Kashima T, Nomizo Y, et al. Metabolism of warfarin enantiomers in Japanese patients with heart disease having different CYP2C9 and CYP2C19 genotypes. Clin Pharmacol Ther. 1998; 63(5): 519-528.

27. Higashi MK, Veenstra DL, Kondo LM, et al. Association between CYP2C9 genetic variants and anticoagulation-related outcomes during warfarin therapy. JAMA. 2002; 287(13):1690-1698.

28. Limdi NA, McGwin G, Goldstein JA, et al. Influence of CYP2C9 and VKORC1 1173C/T genotype on the risk of hemorrhagic complications in African-American and European-American patients on warfarin. Clin Pharmacol Ther. 2008; 83(2):312-321.

29. Furuta T, Ohashi K, Kamata T, et al. Effect of genetic differences in omeprazole metabolism on cure rates for Helicobacter pylori infection and peptic ulcer. Ann Intern Med. 1998; 129(12):1027-1030.

30. Furuta T, Shirai N, Takashima M, et al. Effects of genotypic differences in CYP2C19 status on cure rates for Helicobacter pylori infection by dual therapy with rabeprazole plus amoxicillin. Pharmacogenetics. 2001; 11(4):341-348.

31. Mo SL, Zhou ZW, Yang LP, Wei MQ, Zhou SF. New insights into the structural features and functional relevance of human cytochrome P450 2C9. Part I. Curr Drug Metab. 2009; 10(10):1075-1126.

32. Sim SC. CYP2CP allele nomenclature. Home page of the Human Cytochrome P450 (CYP) Allele Nomenclature Committee [website on the Internet]. Human Cytochrome P450 (CYP) Allele Nomenclature Committee; 2011 [updated May 2]. Available from: http://www. cypalleles. ki.se/cyp2c9.htm. Accessed September 28, 2011.

33. Takahashi H, Wilkinson GR, Nutescu EA, et al. Different contributions of polymorphisms in VKORC1 and CYP2C9 to intra- and interpopulation differences in maintenance dose of warfarin in Japanese, Caucasians and African-Americans. Pharmacogenet Genomics. 2006; 16(2):101-110.

34. Rettie AE, Wienkers LC, Gonzalez FJ, Trager WF, Korzekwa KR. Im paired (S)-warfarin metabolism catalysed by the R144C allelic variant of CYP2C9. Pharmacogenetics. 1994; 4(1):39-42.

35. Lee CR, Goldstein JA, Pieper JA. Cytochrome P450 2C9 polymorphisms a comprehensive review of the in-vitro and human data. Pharmacogenetics. 2002; 12(3):251-263.

36. Sullivan-Klose TH, Ghanayem BI, Bell DA, et al. The role of the CYP2C9-Leu359 allelic variant in the tolbutamide polymorphism. Pharmacogenetics. 1996; 6(4):341-349.

37. Klein TE, Altman RB, Eriksson N, et al. Estimation of the warfarin dose with clinical and pharmacogenetic data. N Engl J Med. 2009; 360(8):753-764

38. Shin J, Cao D. Comparison of warfarin pharmacogenetic dosing algorithms in a racially diverse large cohort. Pharmacogenomics. 2011; 12(1):125-134.
39. Wu AH, Wang P, Smith A, et al. Dosing algorithm for warfarin using CYP2C9 and VKORC1 genotyping from a multi-ethnic population: comparison with other equations. Pharmacogenomics. 2008; 9(2): 169178.

40. Sconce EA, Khan TI, Wynne HA, et al. The impact of CYP2C9 and VKORC1 genetic polymorphism and patient characteristics upon warfarin dose requirements: proposal for a new dosing regimen. Blood. $2005 ; 106(7): 2329-2333$

41. Küpfer A, Desmond PV, Schenker S. Family study of a genetically determined deficiency of mephenytoin hydroxylation in man [letter]. Pharmacologist. 1979; 21:173.

42. Sim SC. CYP2C9 allele nomenclature. Home page of the Human Cytochrome P450 (CYP) Allele Nomenclature Committee [website on the Internet]. Human Cytochrome P450 (CYP) Allele Nomenclature Committee; 2011 [updated May 2]. Available from: http://www. cypalleles. ki.se/cyp2c19.htm. Accessed June 29, 2014.

43. Patrono C, Baigent C, Hirsh J, Roth G; American College of Chest Physicians. Antiplatelet drugs: American College of Chest Physicians Evidence-Based Clinical Practice Guidelines (8th Edition). Chest. 2008; 133(6 Suppl):S199-S233.

44. Chen ZM, Jiang LX, Chen YP, et al. Addition of clopidogrel to aspirin in 45,852 patients with acute myocardial infarction: randomised placebocontrolled trial. Lancet. 2005; 366(9497):1607-1621.

45. Yusuf S, Zhao F, Mehta SR, et al. Effects of clopidogrel in addition to aspirin in patients with acute coronary syndromes without ST-segment elevation. N Engl J Med. 2001; 345(7):494-502.

46. Steinhubl SR, Berger PB, Mann JT 3rd, et al. Early and sustained dual oral antiplatelet therapy following percutaneous coronary intervention: a randomized controlled trial. JAMA. 2002; 288(19): 2411-2420.

47. Combescure C, Fontana P, Mallouk N, et al. Clinical implications of clopidogrel non-response in cardiovascular patients: a systematic review and meta-analysis. J Thromb Haemost. 2010; 8(5):923-933.

48. US Food and Drug Administration. FDA announces new boxed warning on Plavix: alerts patients, health care professionals to potential for reduced effectiveness [press release]. Silver Spring, MD: US Food and Drug Administration; 2010 [March 12]. Available from: http://www. fda. gov/NewsEvents/Newsroom/PressAnnouncements/ucm204253. htm. Accessed June, 2014.

49. Scott SA, Sangkuhl K, Gardner EE, et al. Clinical Pharmacogenetics Implementation Consortium Guidelines for Cytochrome P450-452C19 (CYP2C19) Genotype and Clopidogrel Therapy. Clin Pharmacol Ther. 2011; 90(2):328-332.

50. Saitoh T, Fukushima Y, Otsuka H, et al. Effects of rabeprazole, lansoprazole and omeprazole on intragastric $\mathrm{pH}$ in CYP2C19 extensive metabolizers. Aliment Pharmacol Ther. 2002; 16(10):1811-1817.

51. Shirai N, Furuta T, Xiao F, et al. Comparison of lansoprazole and famotidine for gastric acid inhibition during the daytime and night-time in different CYP2C19 genotype groups. Aliment Pharmacol Ther. 2002; 16(4):837-846.

52. Koukouritaki SB, Manro JR, Marsh SA, et al. Developmental expression of human hepatic CYP2C9 and CYP2C19. J Pharmacol Exp Ther. 2004; 308(3):965-974

53. Shirai N, Furuta T, Moriyama Y, et al. Effects of CYP2C19 genotypic differences in the metabolism of omeprazole and rabeprazole on intragastric pH. Aliment Pharmacol Ther. 2001; 15(12): 1929-1937.

54. Kirchheiner J, Keulen JT, Bauer S, Roots I, Brockmöller J. Effects of the CYP2D6 gene duplication on the pharmacokinetics and pharmacodynamics of tramadol. J Clin Psychopharmacol. 2008; 28(1): 78-83.

55. Gasche Y, Daali Y, Fathi M, et al. Codeine intoxication associated with ultrarapid CYP2D6 metabolism. N Engl J Med. 2004; 351(27): 28272831.

56. Dalén P, Frengell C, Dahl ML, Sjöqvist F. Quick onset of severe abdominal pain after codeine in an ultrarapid metabolizer of debrisoquine. Ther Drug Monit. 1997; 19(5):543-544.

57. Madadi P, Ross CJ, Hayden MR, et al. Pharmacogenetics of neonatal opioid toxicity following maternal use of codeine during breastfeeding: a case-control study. Clin Pharmacol Ther. 2009; 85(1):31-35. 